\title{
Distributor service quality in Indian SMEs: A bi-directional customer perspective
}

\author{
Surjit Kumar Gandhi", Anish Sachdeva and Ajay Gupta
}

Department of Industrial and Production Engineering, Dr. B. R. Ambedkar National Institute of Technology, Jalandhar-144 011, Punjab, India

\begin{tabular}{l}
\hline C H R O N I C L E \\
\hline Article history: \\
Received December18, 2017 \\
Accepted March 282018 \\
Available online \\
March 282018 \\
\hline Keywords: \\
Service Quality \\
Small and medium sized \\
Enterprises (SMEs) \\
Service Quality factors distributor \\
EFA \\
CFA \\
SEM
\end{tabular}

\begin{abstract}
A B S T R A C T
This study investigates the role played by service quality at manufacturer-distributor junction in small-medium manufacturing units, and presents a model that proposes and validates that contribution towards service quality on behalf of both the distributor and manufacturer leading to satisfaction as well as loyalty. The research design for this study includes a combination of literature review, exploratory interviews and a questionnaire survey conducted through interview schedule from 101 respondents working in different small-medium manufacturing units (SMEs) of North India. The study uses Structural Equation Modeling (SEM) to develop dual directional scales to measure service quality at manufacturer-distributor junction besides testing a set of propositions related to service quality. A model showing linkages of manufacturing organization's service quality with distributor service quality leading to mutual satisfaction and loyalty is developed. The model is empirically tested and is found to be fit. This study would be of interest to SME practitioners interested in improving service quality w.r.t. distributors. This study finds support for strengthening relationships with distributors to achieve a win-win situation. Future researchers may validate this scale, and empirically test the proposed model in similar settings. Insights derived from this study may be transferred to other junctions of a manufacturing supply chain such as suppliers, retailers, employees and end customers.
\end{abstract}

\section{Introduction}

In the supply chain of a simple manufacturing unit, distributors serve as a link between production and consumption (Merritt \& Newell, 2001; Shipley \& Jobber, 1994), and act as marketing intermediaries (Gupta \& Singh, 2015). Through interpersonal links with manufacturers, distributors offer inventory management, order processing, and manage sales activity (Mudambi \& Aggarwal, 2003; Erol \& Ferrell, 2004). Distributors create value by achieving a high quality-to-cost ratio in the various functions that they perform (Cavusgil et al., 2004). Distributors also create value through activities such as Customer Relationship Management (which includes customer relationship building, increasing customer base etc.), production and operations Management (including order processing activities, working capital and inventory reduction, lead time reduction, and trade, credit and financing activities, etc.), and * Corresponding author Tel.: 9872891712

E-mail address: skgandhi21@gmail.com (S. K. Gandhi)

C 2018 by the authors; licensee Growing Science, Canada doi: $10.5267 /$ j.uscm.2018.3.002 
knowledge management (including technical product/process knowledge, market knowledge, etc.) (Mudambi \& Aggarwal, 2003). Instead of performing marketing and distribution themselves, manufacturing units are increasingly engaging distributors for distribution and marketing activities (Parmata, 2016) while maintaining their focus on their own core competencies (Sink and Langley, 1997). Long-term, collaborative and reciprocal relationships between distributors and manufacturing units result in higher level of performance for both partners (Cavusgil et al., 2004; Kalafatis, 2002).

Distributor service quality (DSQ) refers to the degree of effectiveness and efficiency with which distribution firm serves the marketing and distribution function desired by the manufacturing unit and what attitudes they hold towards the unit. The positive attitude with which manufacturing organization facilitates the functioning and working of distribution firm is referred as Organizational service quality (OSQ). Small-medium manufacturing units prefer to have very few though reliable distributors, and many a times relying on a sole source. In an attempt to regain their competitiveness, these units should adopt the Japanese Keiretsu system of supply chain partners working in lockstep (Macduffe \& Helper, 1997; Abasi et al., 2015). For supply chain effectiveness, manufacturers and distributors need to keep costs across the supply chain low so that they result in lower market prices and higher margins. This is akin to gain-sharing arrangements wherein everyone who contributes to greater profitability is rewarded.

SMEs occupy a place of strategic importance in the economic growth of any country. With globalization, domestic economic liberalization and sector-specific reforms, these enterprises are finding themselves in an intensely competitive environment. To remain competitive, the need for such units is to develop into a relationship-focused bond with distributors (Prakash, 2011). Though, the output delivered by distributor firm is a well explored area in literature but fewer studies are seen on the applicability of service quality attributes at manufacturer-distributor interface in SMES. Thus there seems to be a major gap in the concept of visualizing the attributes of DSQ and OSQ, followed by developing a model to establish their linkages with satisfaction and loyalty.

In this paper, a focused review of literature was made to develop an instrument for conducting a questionnaire survey. Application of EFA, CFA and SEM brings out a model to answer these questions. Finally, some limitations, which may become future research directives along with the concluding remarks, are presented in the final section of the paper.

\section{Literature review}

Management of successful business enterprises in today's competitive marketplace is a significant challenge. Competitive market put some pressure on today's contemporary business environments have encouraged the partnership of many supply chain members. Of particular interest is the development of successful relationship between firms in an effort to improve product and service quality and efficiency. The formation of manufacturer-distributor partnerships has emerged as a significant trend in marketing channel relationships. Various researchers (Bowersox et al. 1999; Lambert et al., 1999) have also highlighted that successful partnerships and relationship integration throughout the supply chain have the potential to render efficiencies, profits and service. With reference to logistics, the focus of the literature is on traditional measures of customer service such as availability, timeliness and delivery quality (Morris \& Carter, 2005; Dahistrom et al., 1996; Emerson \& Grimm, 1996; Mentzer et al., 1989). Though these measures are mostly related to delivery, other criteria such as those related to manufacturing unit's evaluation in the areas of customer relationship and communication (Simpson et al., 2002), and manufacturing unit-distributor relationships can be added to evolve more comprehensive measures of customer service. The use of support services by manufacturing unit (Frazier, 1983) and

provision of supplementary services such as, after sales support and total service capability (Hunt and Jones, 1998) reveal the value of relationships between two partners. 
Winning and preserving the allegiance of distributors recently has become a more challenging task for manufacturing units. Rapid global changes in the environments of industrial markets make distributor commitment more important and in some ways difficult to achieve (Goodman \& Dion, 2001). Ma and Deng (2002) also advocate that the distribution part plays a crucial role in the management of a supply chain, so particularly separated it form general supply chain and defined it as distribution chain.

Bookbinder and Lynch (1997) proposed several models to address the tradeoffs between service levels and cost through utility function approach. Utility is the satisfaction which a person receives from consuming commodities or service (Farquhar, 1984).

Numerous researchers advocated for manufacturing-distributor partnerships and alliances. They advocated for replacing short-term oriented exchanges with relational exchanges such as working partnerships (Anderson \& Narus, 1990), strategic alliances (Bucklin \& Sengupta, 1993), just-in-time relationships (Frazier et al., 1988; Nadali et al., 2017) and successful partnerships through planning and information sharing (Joseph et al., 1995). Dwyer et al. (1987) suggest that strong commitment may be necessary before other aspects of close relationships between channel members, such as a working partnerships or trust, can develop. Li and Lee (1994) find that in modeling competition between two otherwise equal firms, the one furnishing better service enjoys a larger market share and a price premium. A higher quality service is thus presumed to lead greater sales revenue. Ozment and Chard (1986) note, however, that when competing suppliers all offer high fill rates, say, the result may be no statistically significant relationship between fill rate and sales.

Researchers agree that success can be predicated upon the level of commitment both firms make to the relationship and their understanding of mutual needs (Narus \& Anderson, 1986, 1988). Morgan \& Hunt (1994) and Gundlach et al. (1995) further highlight the crucial role of commitment for successful relations between trading partners. Erol and Ferrell (2004) did a study for improved understanding of distributor commitment in channel relationships and also suggested an approach for measuring distributor commitment. It is clear that an excellent product is no longer sufficient, by itself, to retain customer loyalty. Consumers expect the whole package, which includes distribution service, availability of stock, and reliable delivery (Erengüç et al., 1995; Kumar \& Sharman, 1992). Pisharodi and Langley (1991) also found a strong relationship between market response (purchase volume) and customer's perceptions of service. Towards the evaluation of service quality, Siu and Cheung (2001) suggested a validated scale to measure retail service quality delivery of a departmental store chain and its impact on consumption behavior. They suggested six dimensions namely: personal interaction, policy, physical appearance, promises, problems solving and convenience.

Researchers have addressed the subject of distributor relation from different perspectives. Smith et al. (1997) investigated the relationship of a distributor with two suppliers in terms of steps leading to relationship development, shared activities, implementation and evaluation of these processes. A physical distribution service quality (PDSQ) measurement tool to study the relationship between internal customer's perceptions of their supplier's PDSQ and future purchase intentions identified timeliness, availability and condition as key dimensions of PDSQ (Bienstock et al., 1997). Das and Tyagi (1994) developed a decision support system for the integrated service and distribution system utilizing mixed integer programming (MIP) model to minimize the total operation costs subject to satisfying certain service requirements of both manufacturers and retailers. Cavusgli et al. (1995) developed an expert system for the evaluation and selection of a foreign distributor. They evaluated a distributor from five aspects: financial and company strength, product factors, marketing skills, commitment, and facilitating factors. Min and Melachrinoudis (1999) developed a model for the relocation of a hybrid manufacturing and distribution facility. In attempt to measure distribution service quality, Mentzer et al. (1989) reviewed the physical distribution literature to specify the domain of distributor service delivery and classified according dimensions of timeliness, availability and quality. Although considerable research has been conducted on distributor relationship management or distribution but most of these studies are conceptual in nature or with focus on supplier's perspective. 
Also the researchers have preferred to assess distributor's performance through modeling and covered mainly finance related aspects. Thus, from the point of view of theory development, there is a merit in attempting to extend the domain of services quality research from retail or end use customer to distributor context as well as the exploration of alternative dimensions of service quality.

An understanding of the manufacturer-distributor relationship helps build loyalty and customer retention over the long term (Ma et al., 2004). Distribution service ensures time and place utility by making products available when and where they are required (Ahmad et al., 2009; Perreault \& Russ, 1976). Distributor relationships have a time and purpose dimension. For a planning and control process that communicates relevant information to support the operations, it is essential to build and maintain relationships. Implementation of shop floor control systems to facilitate distribution function has valueenhancing benefits for manufacturing and supply chain activities (Abdul-Muhmin, 2002; Gaski, 1984). Commitment and trust between the manufacturing unit and the distributor form the foundation of mutual relationships. Empirical research demonstrates that satisfaction among supply chain partners is a determinant of the success of a relationship (Patterson et al., 1997; Schellhase et al., 2000), and that satisfied partners invest more resources into the relationship, thereby resulting in sustainable advantages to both partners. In the literature on distribution, factors such as power, trust, dependence, and the nature and number of conflicts are known to influence satisfaction (Anderson \& Narus, 1990; Dwyer, 1980; Frazier, 1983; Wilkinson, 1981). Strong positive relationships are characterized by concern, trust, commitment, and excellent service levels (Buttle, 1996), and are an outcome of good internal service quality. Partnership and relationship integration throughout the supply chain have been empirically shown to enhance efficiency and service (Bowersox et al., 1999; Lambert et al., 1999). The manufacturer-distributor partnership is thus regarded key to successful marketing channel relationships (Joseph et al., 1995). The study is conducted in exploratory framework using structured interview schedule. The framework shown in Fig. 1 represents the possible relationship among the variables, which will be tested.

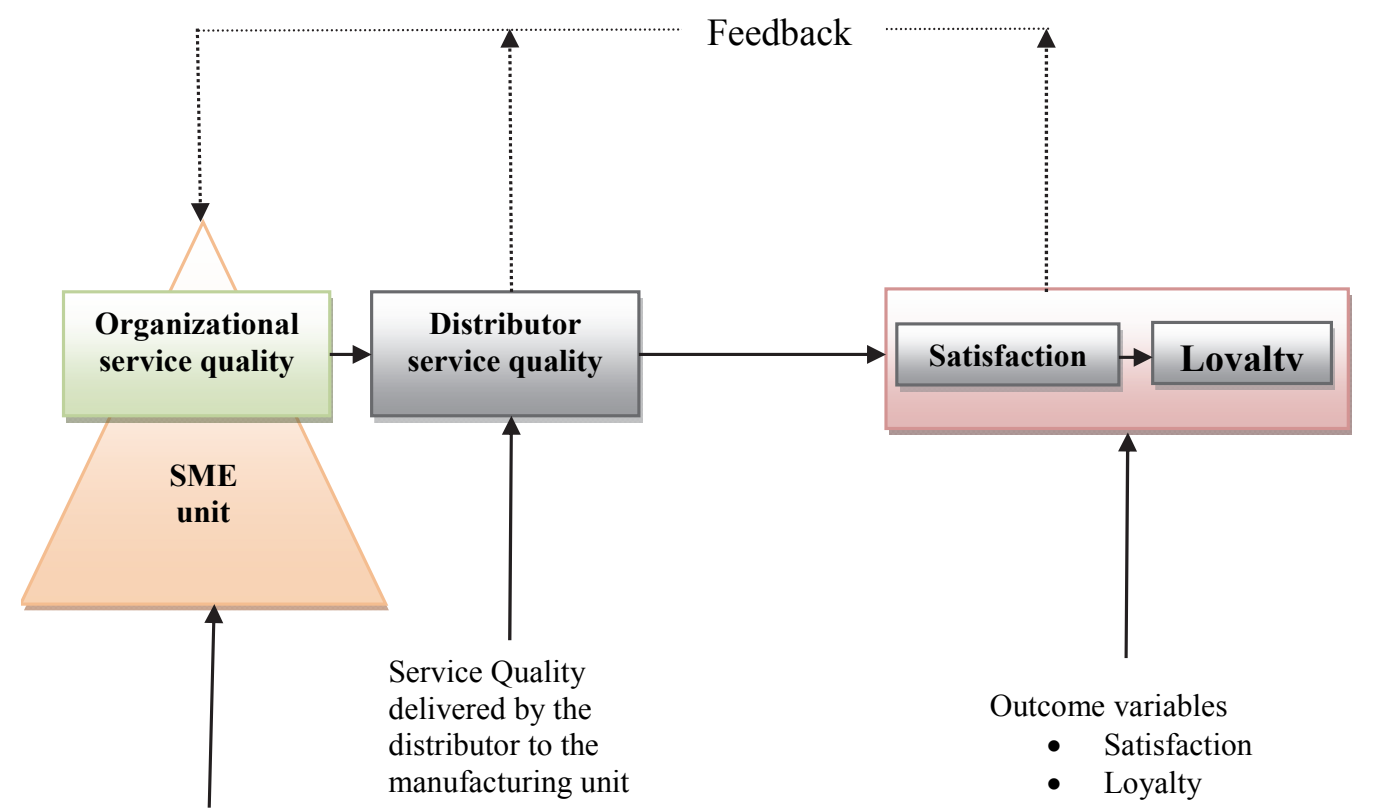

Service Quality

Offered by the

Manufacturing unit

to the distributor

Fig. 1: Conceptual Research Framework

Parasuraman et al. $(1985,1988)$ in their pioneering work identified five components of service quality viz. reliability, assurance, tangibles, empathy, and responsiveness. These five dimensions used to 
evaluate service quality are called SERVQUAL dimensions. Carr (2007) proposed an important deficiency of SERVQUAL scale by stating that it does not include equity theory as the basis for any of its scales, even if it is clear from previous experience that equity (fairness) is often evaluated in service encounters. FAIRSERV (Carr, 2007), in conjunction with SERVQUAL (Parasuraman et al. 1988), may be suitable for this study, due to its focus on satisfaction and loyalty intensions. The preliminary questionnaire is on five attributes of SERVQUAL scale and "Systematic Fairness" dimension of FAIRSERV model. Taking cues from both existing scales to measure service quality, we have made a modest attempt at designing a new scale based on the combination of the two metrics as shown in Fig. 2.

In this study, service quality was treated as independent or antecedent variable. Satisfaction from distributor's working was treated as a mediating factor, which affects the relationship between service quality and outcome variables, while service quality also affects customer satisfaction. Customer loyalty was treated as outcome variable. Figure 2 also shows the relationship of the Independent, Mediating and Dependent variables used in this study.

\section{Research methodology}

Fig. 3 shows the research methodology used for determining factors of organizational service quality (OSQ) and distributor service quality (DSQ) followed by establishing their linkages with satisfaction and loyalty. This methodology is based on the work of Seth et al. (2006) and Prakash (2011).

\section{Service Quality}

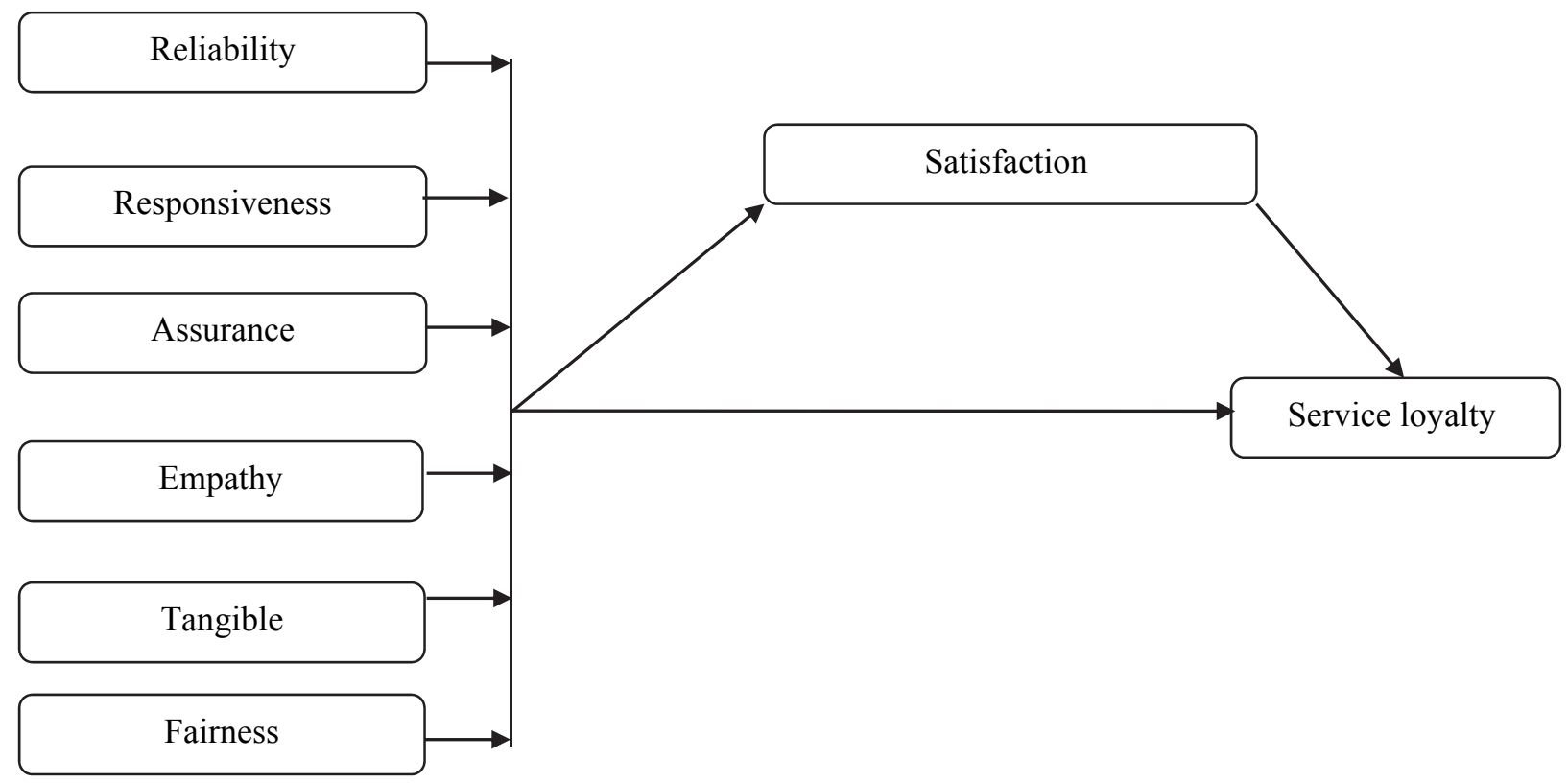

Fig. 2. Relationship between Independent, Mediating and Dependent Variables

A survey instrument was developed based on an extensive review of literature on different aspects of service quality measurement with a focus on employee related issues using a combination of SERVQUAL (Parasuraman et al., 1985, 1988) and FAIRSERV (Carr, 2007) scales. The questionnaire was refined after focus group discussion with five managers working in different SMEs and three academicians with work published in similar area. Morgan (1993) recommends such refinement of existing measurement instruments when the population for the research is new as in this case. The questionnaire thus emerged comprised four sections as follows: 
- Section-A consists of 25 items related to service quality delivered by distributor (DSQ) and 1 item measuring overall distributor service quality (ODSQ).

- Section-B comprises 24 items related to service quality offered by the manufacturing organization towards its distributor (OSQ) and 1 item measuring overall organizational service quality (OOSQ).

- Section-C consists of two outcome variables viz. satisfaction (mapped by 2 items) and loyalty (mapped by 3 items).

- Section-D focuses focused on gathering the demographic information.

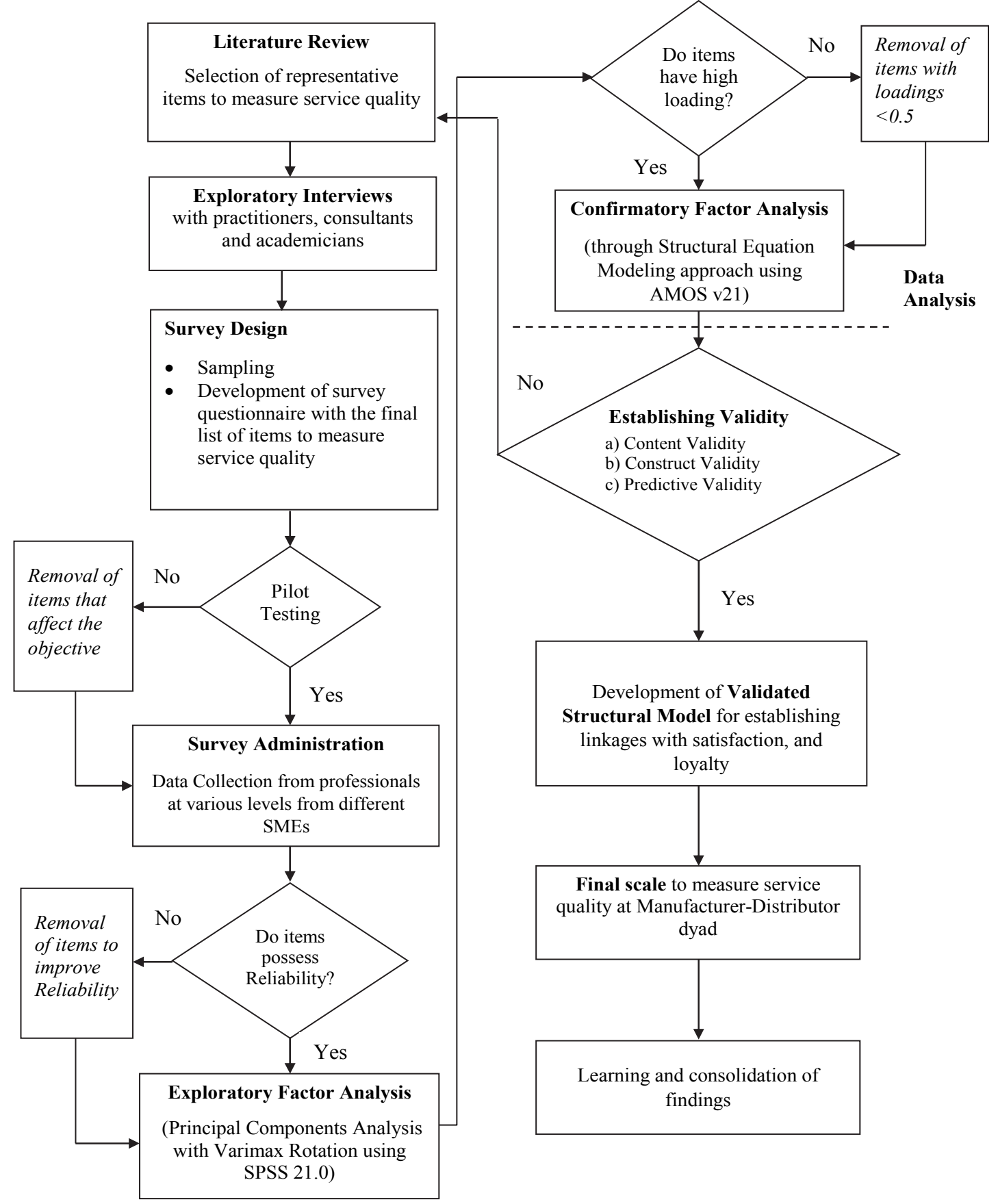

Fig. 3. Flow chart of research methodology adopted for measurement and modeling of service quality at Manufacturer-Distributor interface 
Prior to circulation, the questionnaire was authenticated through a pilot survey (Robson, 2002). This was done to know any discrepancies, duplicity or lack of understanding of the questionnaire by the respondents. Their suggestions were incorporated and questionnaire was revised. The pre-test of the questionnaire was conducted during January, 2017 and the survey was administered during MarchJuly, 2017.

Data was collected by personally visiting the respective units. There was no specific choice in selecting the industry from any specific sector. The method of snowball sampling was used to make direct contact with professionals and to execute this survey. Respondents were asked to enter their perceptions of service quality on 5-point Likert scale. Prior to the commencement of the data collection, introductory e-mails were sent out to plant heads of respective units. Plant heads referred the researcher to the key respondents, who could be contacted for filling-in the questionnaires. The respondents were initially briefed about the questionnaire and the Likert scale besides the explanation of the items contained in questionnaire, so as to obtain more consistent responses. The respondent's own personal privacy was kept secret. This helped to achieve unbiased responses as suggested by Robson (2002) and Saunders et al. (2009). Most of the respondents themselves filled-in the questionnaire at the time the researcher approached them, while other respondents kept the questionnaires, and returned them to the researcher in subsequent visits. The purpose of this approach was to enhance the response rate and improve the quality of data. This approach has been endorsed by other scholars in the literature (Flynn et al., 1990; Forza, 2016; Kang \& Bradley, 2002; Finn \& Lamb, 1991; Zhao et al., 2002; Dabholkar et al., 2000; Devinder \& Datta, 2003; Cunningham \& Young, 2002).

The researcher approached 165 respondents serving in different small-medium manufacturing units and was able to elicit data from 101 respondents, thus fetching a response rate of $61 \%$ which was quite satisfactory. Many of the non-respondent SME units were themselves performing marketing/distribution function. This high rate of response may be attributed to involvement and commitment of unit heads of respective units and personal visits by the researcher to collect data. The type of manufacturing activity being carried by the respondent units is shown in Table 1.

\section{Data analysis}

Since the items of the scale along with their underlying factors, which are used to measure OSQ and DSQ, are derived from the literature. Thus, the imperative is first to assess the scales. For this purpose, reliability analysis, Exploratory Factor Analysis (EFA) and Confirmatory Factor Analysis (CFA) have been performed.

\section{Table 1}

Type of product being manufactured by respondent SMEs $(\mathrm{N}=101)$

\begin{tabular}{lcc}
\hline Type of Manufacturing Unit & Small Scale & Medium Scale \\
\hline Number \& Percentage & $60(59 \%)$ & $41(41 \%)$ \\
\hline Type of Product & & \\
\hline Auto Parts & $21(\approx 21 \%)$ & $13(\approx 13 \%)$ \\
Hand Tools & $12(\approx 12 \%)$ & $7(\approx 7 \%)$ \\
Casting Components & $6(\approx 6 \%)$ & $5(\approx 5 \%)$ \\
Valve manufacturing/Casting & $8(\approx 8 \%)$ & $4(\approx 4 \%)$ \\
Rolled Products & $4(\approx 4 \%)$ & $4(\approx 4 \%)$ \\
Machine Tools & $3(\approx 3 \%)$ & $3(\approx 3 \%)$ \\
Sheet Metal Components & $2(\approx 2 \%)$ & $3(\approx 3 \%)$ \\
Fasteners & $2(\approx 2 \%)$ & $2(\approx 2 \%)$ \\
Multi Products & $2(\approx 2 \%)$ & Nil \\
\hline
\end{tabular}

The demographic distribution of respondents is presented in Table 2. 
Table 2

Demographic distribution of respondents

\begin{tabular}{lcclllllc}
\hline \multicolumn{1}{c}{ Experience } & & \multicolumn{1}{c}{ Qualification } & \multicolumn{3}{c}{ Functional Area of work } \\
\hline \multicolumn{1}{c}{ Distribution } & $\mathrm{n}$ & $\%$ & \multicolumn{1}{c}{ Distribution } & $\mathrm{n}$ & $\%$ & \multicolumn{1}{c}{ Department } & $\mathrm{n}$ & $\%$ \\
\hline up to 5 years & 37 & 36 & MBA/M.Tech./M.Sc. & 11 & 11 & Distribution & 44 & 43 \\
6-10 years & 21 & 21 & BBA/B.Tech./B.Sc. & 38 & 37 & Procurement/Store & 23 & 23 \\
11-15 years & 24 & 24 & MA/BA/B.Com. & 20 & 20 & Marketing/Sales & 26 & 26 \\
16-20 years & 11 & 11 & Technical Diploma & 22 & 22 & Production & 5 & 5 \\
above 20 years & 8 & 8 & Intermediate/below & 10 & 10 & Quality Control & 3 & 3 \\
\hline
\end{tabular}

\subsection{Reliability Analysis}

The reliability of both OSQ and DSQ scales was analyzed using Cronbach alpha coefficient. Output of this analysis is provided by IBM SPSS v2 1 and indicates significantly high reliability of data (Cronin \& Taylor 1992; Lee et al., 2000) and is depicted in Table 3.

\section{Table 3}

Reliability Analysis of items in OSQ and DSQ scale

\begin{tabular}{lcc}
\hline Service Quality Measurement & OSQ items $(\mathrm{n}=24)$ & DSQ items $(\mathrm{n}=25)$ \\
\hline Value of $\alpha$ & 0.867 & 0.898 \\
Finding & Quite Good (Nunnally and Bernstein, 1978). \\
\hline
\end{tabular}

\subsection{Factor Analysis}

Prior to application of EFA, Bartlett test of Sphericity is used to verify appropriateness of factor analysis by analyzing correlation matrix of the data (Hair et al., 2005). Simultaneously, assessment of sampling adequacy ( $\mathrm{N}=101$, in this case) is judged by Kaiser-Meyer-Olkin (KMO) statistics which ranges from 0 to 1 . The KMO value of above 0.6 is considered significant and indicates suitability of factor analysis. The score of Bartlett test of Sphericity and the KMO value is provided by SPSS v21 and is depicted in table 4 . The results are significant, thus, providing indication of suitability for factor analysis (Hair et al., 2010).

\section{Table 4: KMO and Bartlett's Test of sphericity}

\begin{tabular}{lccc}
\hline \multirow{2}{*}{ KMO Measure for Sampling Adequacy } & & OSQ scale & DSQ scale \\
\cline { 3 - 4 } Bartlett's Test of Sphericity & Approx. Chi-Square & .830 & .837 \\
& $\mathrm{df}$ & 2631 & 2221 \\
& Sig. & 300 & 231 \\
& & .000 & .000 \\
\hline
\end{tabular}

EFA is conducted using the Principle Component Analysis (PCA) with Kaiser Normalization (Eigen values greater than 1) and varimax rotation procedure. The objective is to summarize the information asked in the questions into a smaller set of new attributes that attempt to bring out the constructs for measurement of service quality offered to employees by the manufacturing unit.

This resulted in the extraction of five factors each for OSQ and DSQ scale, explaining 74.986 and 75.286 per cent of the variance respectively. These factor loadings are consistent with the suggested factor structure of the scale. Output of exploratory factor analysis using SPSS v21 is presented in Table 5 and Table 6. 
Table 5

Communalities, Factor Structure and Loadings for Items of OSQ

Principal Components Method with Varimax Rotation Loading $\geq .53 *$

\begin{tabular}{|c|c|c|c|c|c|c|c|}
\hline \multirow[t]{2}{*}{ S. No. } & \multirow[t]{2}{*}{ Factors and Associated Items } & \multirow[t]{2}{*}{ Communalities } & \multicolumn{5}{|c|}{ Factor Structure \& loadings } \\
\hline & & & F1 & F2 & F3 & $\mathrm{F} 4$ & F5 \\
\hline \multicolumn{8}{|c|}{ Trust (F1) } \\
\hline 1. & Long term collaborative relationship & .761 & .865 & & & & \\
\hline 2. & The unit is honest in sharing information & .848 & .909 & & & & \\
\hline 3. & Shares information related to inventory & .843 & .908 & & & & \\
\hline 4. & The unit maintains confidentiality in operations & .888 & .931 & & & & \\
\hline 5. & Shares information related to future plans & .812 & .892 & & & & \\
\hline 6. & Shares market developments with distributor & 675 & .813 & & & & \\
\hline \multicolumn{8}{|c|}{$E O D B(F 2)$} \\
\hline 7. & Excellent terms \& conditions in dealings & .515 & & .630 & & & \\
\hline 8. & Has latest $\&$ adequate physical facilities & .817 & & .888 & & & \\
\hline 9. & The unit is conveniently approachable & .633 & & .725 & & & \\
\hline 10. & Share information regarding quality \& feedback & 615 & & .666 & & & \\
\hline 11. & IT to support communication of information & .793 & & .868 & & & \\
\hline 12. & Equitable distribution of responsibility & .823 & & .887 & & & \\
\hline 13. & Offer price advantage to the distributors & .587 & & .646 & & & \\
\hline \multicolumn{8}{|c|}{ Alignment (F3) } \\
\hline 14. & Adapts to shifts in market & .760 & & & .828 & & \\
\hline 15 . & Pays attention to distributor's viewpoint & .872 & & & .865 & & \\
\hline 16. & Shows respect and positive attitude & .883 & & & .916 & & \\
\hline 17. & Strives for convenience of distributor & .855 & & & .896 & & \\
\hline \multicolumn{8}{|c|}{ Promptness-Courtesy (F4) } \\
\hline 18. & You willingly do work requested by distributor & .661 & & & & .871 & \\
\hline 19. & Distributor's complaints are solved quickly & .782 & & & & .835 & \\
\hline 20. & You treatment with distributors is respectful & .755 & & & & .843 & \\
\hline 21. & Maintains courtesy \& politeness in dealings & .811 & & & & .797 & \\
\hline \multicolumn{8}{|c|}{ Credibility (F5) } \\
\hline 22. & Use right tools/equipment/ modern technology & .689 & & & & & .766 \\
\hline 23. & Prepares accurate dispatch notes & .662 & & & & & .723 \\
\hline 24. & Share knowledge/training with its distributors & 658 & & & & & .727 \\
\hline Reliabi & ty (Cronbach Alpha Value) of identified factors & & .904 & .907 & .930 & .887 & .759 \\
\hline
\end{tabular}

As shown in Table 5, based upon subjective opinion of the researcher in consultation with a group of experts, the factors were named as Trust, Ease of Doing business (EODB), Tangibles, Empathy, and Credibility. All the items have significant communalities (not less than 0.50) (Hair et al., 2010) and significant factor loadings (not less than 0.55) (Pitt et al., 1995). Internal reliability of the items of the various factors of the OSQ scale is examined using the Cronbach alpha coefficients. This approach is in line with that of Bagozzi and Yi (1988). In this analysis, reliability score for each factor ranges from $75.9 \%$ to $93.0 \%$ as shown in table 5 and hence is acceptable (Nunnally \& Bernstein, 1978).

Likewise as shown in Table 6, the five factors were named as: Customization, Assurance-Agility, Responsiveness, Tangibles-Empathy, and Reliability. All the items have significant communalities (not less than 0.50) (Hair et al., 2010) and factor loadings (not less than 0.55) (Pitt et al., 1995). The reliability score for each factor ranges from $83.6 \%$ to $95.0 \%$ as shown in Table 6 and hence is acceptable (Nunnally \& Bernstein, 1978). 
Table 6

Communalities, Factor Structure and Loadings for Items of DSQ Scale

Principal Components Method with Varimax Rotation Loading $\geq .52 *$

\begin{tabular}{|c|c|c|c|c|c|c|c|}
\hline \multirow[t]{2}{*}{ S. No. } & \multirow[t]{2}{*}{ Factors and Associated Items } & \multirow[t]{2}{*}{ Communalities } & \multicolumn{5}{|c|}{ Factor Structure \& loadings } \\
\hline & & & F6 & F7 & F8 & F9 & F10 \\
\hline \multicolumn{8}{|c|}{ Customization (F6) } \\
\hline 1. & Distributor has required knowledge \& skills & .716 & .917 & & & & \\
\hline 2. & Distributor has long term relationship with you & .758 & .876 & & & & \\
\hline 3. & Distributors makes efforts for the market growth & .790 & .925 & & & & \\
\hline 4. & Distributor's employees are competent to serve & .842 & .933 & & & & \\
\hline 5. & Distributor's employees are courteous and polite & .771 & .905 & & & & \\
\hline 6. & Distributor maintains mutually beneficial T\&C & .681 & .900 & & & & \\
\hline 7. & Distributors handles the depreciated/unsold stock & .724 & .810 & & & & \\
\hline \multicolumn{8}{|c|}{ Assurance-Agility (F7) } \\
\hline 8. & Distributor has strong market reputation & .712 & & .764 & & & \\
\hline 9. & Distributor has financial strength & .790 & & .845 & & & \\
\hline 10. & Distributor is flexible as per requirements & .806 & & .813 & & & \\
\hline 11. & Distributor is innovative in working & .712 & & .812 & & & \\
\hline 12. & Distributor is easily approachable & .642 & & .741 & & & \\
\hline 13. & Distributor uses ICT to maintain records & .736 & & .821 & & & \\
\hline \multicolumn{8}{|c|}{ Responsiveness (F8) } \\
\hline 14. & Distributor has willingness to serve your unit & .665 & & & .724 & & \\
\hline 15 . & Distributor has quick solutions to complaints & .829 & & & .885 & & \\
\hline & Distributor shares relevant information/feedback & .885 & & & .871 & & \\
\hline 17. & Distributor has positive attitude towards your unit & .856 & & & 670 & & \\
\hline \multicolumn{8}{|c|}{ Tangibles-Empathy (F9) } \\
\hline 18. & Distributor has right equipment/SKUs & .850 & & & & .912 & \\
\hline 19. & Distributor's facilities are certified \& appealing & .914 & & & & .929 & \\
\hline 20. & Distributor understands your requirements & .815 & & & & .916 & \\
\hline 21. & Distributor cares for your convenience & .627 & & & & .889 & \\
\hline \multicolumn{8}{|c|}{ Reliability (F10) } \\
\hline 22. & Distributor delivers correct quantity in right time & .723 & & & & & .794 \\
\hline 23. & Distributor charges minimum margins & .659 & & & & & .709 \\
\hline 24. & Distributor is honest \& trustworthy & .639 & & & & & .763 \\
\hline 25. & Distributor maintains confidentiality & .696 & & & & & .768 \\
\hline Reliabil & y (Cronbach Alpha ${ }^{\#}$ value) of identified factors & & .937 & .916 & .864 & .950 & .836 \\
\hline
\end{tabular}

\subsection{Confirmatory Factor Analysis (CFA)}

CFA is undertaken to further validate the scales for measuring OSQ and DSQ. CFA confirms the factor structure by testing the fit of CFA model. CFA model is run using SPSS AMOS v21, for 5 individual factors each describing OSQ and DSQ scales, with respective items. Table 7 and Table 8 show the key model fit indices for the individual factors.

Table 7

Key fit Indices for measurement model of OSQ

\begin{tabular}{lcccccc}
\hline \multicolumn{1}{c}{ Factors } & $\begin{array}{l}(\chi 2) / \mathrm{df}= \\
\mathrm{Cmin} / \mathrm{df}\end{array}$ & RMR & GFI & NFI & CFI & RMSEA \\
\hline Trust & .938 & .010 & .981 & .991 & 1.000 & .000 \\
EODB & 1.325 & .023 & .962 & .967 & .992 & .057 \\
Alignment & --- & .000 & 1.000 & 1.000 & 1.000 & .000 \\
Promptness-Courtesy & .146 & .005 & .999 & .999 & 1.000 & .000 \\
\hline
\end{tabular}




\begin{tabular}{lllllll}
\hline Credibility & --- & .000 & 1.000 & 1.000 & 1.000 & .000 \\
\hline
\end{tabular}

Table 8

Key fit Indices for measurement model of DSQ

\begin{tabular}{lcccccc}
\multicolumn{1}{c}{ Factors } & $\mathbf{( \chi 2 ) / d f}=\mathbf{C m i n} / \mathbf{d f}$ & $\mathbf{R M R}$ & GFI & NFI & CFI & RMSEA \\
\hline Customization & 1.195 & .009 & .956 & .982 & .991 & .040 \\
Assurance-Agility & 2.256 & .020 & .979 & .985 & .991 & .012 \\
Responsiveness & .686 & .010 & .995 & .996 & 1.000 & .000 \\
Tangibles-Empathy & .079 & .003 & 1.000 & 1.000 & 1.000 & .000 \\
Reliability & 2.422 & .029 & .979 & .971 & .983 & .054 \\
\hline
\end{tabular}

Based on the methodology of Sureshchandar et al. (2002) and Bienstock et al. (1997), the model fit was examined for each factor. Since all the GFI values are above 0.9 , which clearly provides validation of individual factors of CFA model (Hair et al., 2010).

\subsection{CFA matrix development and scale purification}

\subsubsection{CFA matrix development for OSQ and DSQ scale}

In order to develop the measurement scale, the covariance matrices between the five identified factors for both OSQ and DSQ scale was created as shown in Fig. 4 and Fig. 5.

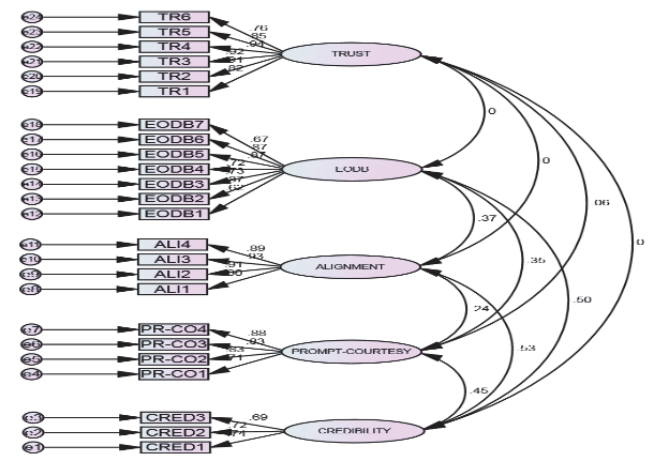

Fig. 4. Theoretical framework for development of OSQ Scale

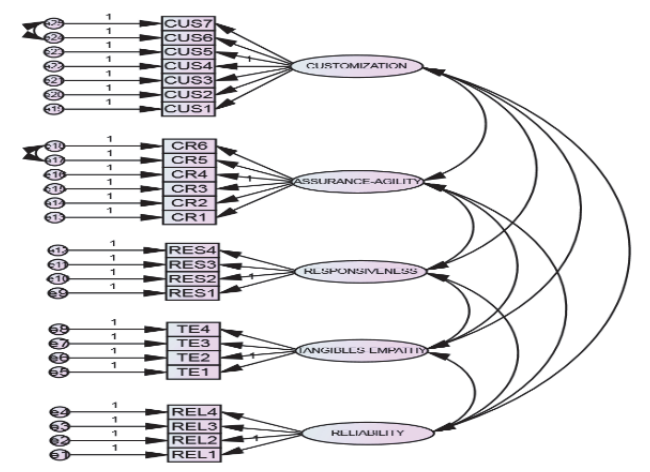

Fig. 5. Theoretical framework for development of DSQ Scale

\subsubsection{CFA matrix purification for OSQ and DSQ scale}

For purification of OSQ scale, three iteration runs of CFA were performed to obtain satisfactory goodness of fit indices. During this process, one dimension viz. Alignment was completely dropped. In total, 10 out of an initial 24 items were deleted, since these items were found to be inadequate on model estimates examination during CFA runs based on the amount of explained variance. This intensity of item deletion is not exceptional in scale development studies as the final scale may contain even one fifth of the original items (Bienstock et al., 1997). The final model consisting of 4 factors and 14 subfactors is depicted in Fig. 6. 


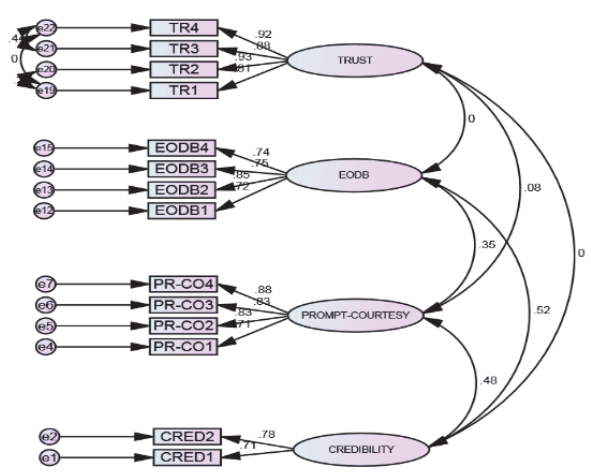

Fig. 6. CFA Model Development for measuring OSQ

Five runs of CFA were performed to obtain satisfactory goodness of fit indices. During this process, one dimension viz. Assurance-Agility was completely dropped. In total, 11 out of an initial 25 items were deleted. The final model consisting of 4 factors and 14 sub-factors is depicted in Fig. 7.

\subsubsection{Model Analysis}

\subsubsection{OSQ scale}

Various goodness-of-fit indices are obtained by running the model using AMOS v 21. The Normed Chi-square value for this model is 1.620 , which represents a good fit. The acceptable ratio of Normed Chi-square value is up to 3 or even 5 (Bollen, 1989; Tanaka, 1987). The Goodness-of-Fit Index (GFI), the Comparative Fit Index (CFI) and the Normed Fit Index (NFI) values for this model were 0.912, 0.972 , and 0.930 respectively. The RMSEA value of 0.066 indicates a reasonable fit. From these values it is inferred that model represents an adequate fit.

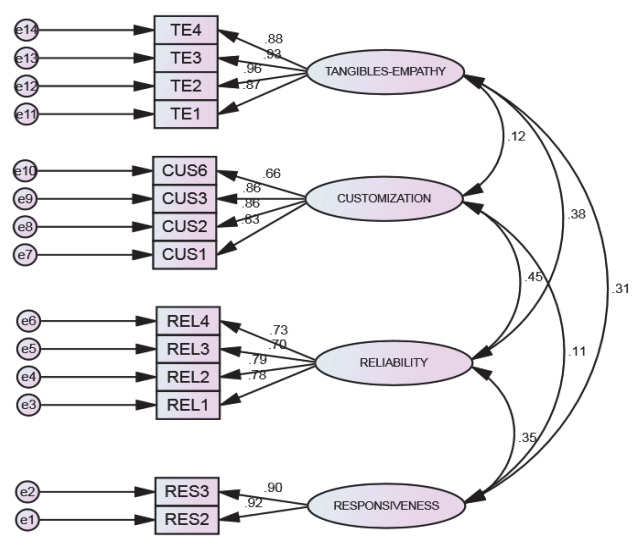

Fig. 7. CFA Model Development for measuring DSQ

\subsubsection{DSQ scale}

The Normed Chi-square value for this model is 1.748 , which represents a good fit. The Goodness-ofFit Index (GFI), the Comparative Fit Index (CFI) and the Normed Fit Index (NFI) values for this model were $0.907,0.958$, and 0.908 respectively. The RMSEA value of 0.072 indicates a reasonable fit. From these values it is inferred that model represents an adequate fit.

\subsubsection{Validity of Construct}

a. Face Validity 
Face validity is assessed by looking at the measures 'on-its-face', which gives a good reflection of both ISQ as well as ESQ (in line with Trochim, 2007).

\section{b. Content Validity}

Content validity of the questionnaire items is satisfactorily assessed by discussions with scholars, insights derived from the literature, and the researcher's own knowledge (Trochim, 2007). Subsequent refinement of this scale was ensured through focus group discussion with representatives from smallmedium manufacturing units. The instrument for both OSQ as well as DSQ thus has strong content validity.

\section{c. Construct Validity}

Construct validity is assessed through following three steps:

i. Unidimensionality: CFA model developed in this analysis indicates CFI value ( 0.957 for OSQ scale and, 1 for DSQ scale) which implies a strong/perfect unidimensionality (Bollen \& Ting, 1993; Bryne, 1994).

ii. Convergent Validity: Convergent validity measures the extent to which different approaches to measuring a construct produces the same results (Ahire et al., 1996). A value of 0.60 or higher for all factor loadings in CFA model developed demonstrates strong convergent validity (Chin et al. 1996). In the CFA models developed, all the factor loadings ranged from 0.67 to 1 in OSQ scale and from 0.70 to 0.96 in DSQ scale; thus all items in the scales developed have strong convergent validity.

iii. Discriminant Validity: Discriminant validity measures the degree to which a construct and its indicators are different from another construct and its indicators (Bagozzi et al., 1991). Fornell and Larcker (1981) suggest that for discriminant validity, square root of the average variance extracted for a given construct, should be greater than the absolute value of the standardized correlation of the given construct with any other construct in the analysis. The square root of AVE for each of the factor is shown in the diagonal cells, and the Correlation Coefficient of a factor with the other factors is shown in the non-diagonal cells of the Table 9 and Table 10.

\section{Table 9}

Results of Discriminant Validity for the scale for measuring OSQ

\begin{tabular}{lcccc}
\multicolumn{1}{c}{ Dimensions } & Trust & EODB & Promptness-Courtesy & Credibility \\
\hline Trust & 0.816 & & & \\
EODB & 0.010 & 0.835 & & \\
Promptness-Courtesy & 0.379 & 0.285 & 0.748 & \\
Credibility & 0.453 & 0.167 & 0.567 & 0.718 \\
\hline
\end{tabular}

The $\sqrt{ } A V E$ is depicted in the diagonal cells and the correlation in other cells

Table 10

Results of Discriminant Validity for the scale for measuring DSQ

\begin{tabular}{lcccc}
\hline Dimensions & Tangibles-Empathy & Customization & Responsiveness & Reliability \\
\hline Tangibles-Empathy & 0.912 & & & \\
Customization & 0.140 & 0.841 & & \\
Responsiveness & 0.308 & 0.086 & 0.912 & \\
Reliability & 0.351 & 0.439 & 0.382 & 0.750 \\
\hline
\end{tabular}

The $\sqrt{ } A V E$ is depicted in the diagonal cells and the correlation in other cells 
Since, the square root of AVE for each of the factors was greater than the Correlation Coefficient of that factor with the other factors, and this supported the discriminant validity of the scale.

\section{d. Predictive Validity}

Predictive validity is established when a criterion external to the measurement instrument is correlated with the factor structure (Nunnally \& Bernstein, 1978).

The predictive validity of the four dimensions of OSQ was measured by finding the correlation of each one of them with mean scores of overall organizational service quality (OOSQ) and Overall Satisfaction perceived by distributor (both being external criteria) using Pearson correlation. All the correlation coefficients were positive and significant at a significance level of 0.05 . The result of correlation analysis is shown in the Table 11.

\section{Table 11}

Correlation of factors of OSQ scale with OOSQ and Overall Satisfaction

\begin{tabular}{lcc}
\hline Factors underlying OSQ & OOSQ & Overall Satisfaction \\
\hline EODB & $.664^{*}$ & $.371^{*}$ \\
Trust & $.636^{*}$ & $.813^{*}$ \\
Credibility & $.624^{*}$ & $.429^{*}$ \\
Promptness-Courtesy & $.607^{*}$ & $.787^{*}$ \\
\hline
\end{tabular}

* Correlation is significant at the 0.05 level (2-tailed).

The predictive validity of the four dimensions of DSQ was measured by finding the correlation of each one of them with mean scores of overall distributor service quality (ODSQ) and overall satisfaction perceived by manufacturing unit (both being external criteria) using Pearson correlation. All the correlation coefficients were positive and significant at a significance level of 0.05 . The results of correlation analysis are shown in the Table 12. This assured the predictive validity of the newly developed scales.

\section{Table 12}

Correlation of factors of DSQ with ODSQ and Overall Satisfaction

\begin{tabular}{lcc}
\hline \multicolumn{1}{c}{ Factors underlying DSQ } & ODSQ & Overall Satisfaction \\
\hline Tangibles-Empathy & $.745^{*}$ & $.498^{*}$ \\
Customization & $.504^{*}$ & $.505^{*}$ \\
Responsiveness & $.522^{*}$ & $.608^{*}$ \\
Reliability & $.510^{*}$ & $.535^{*}$ \\
\hline
\end{tabular}

* Correlation is significant at the 0.05 level (2-tailed).

\section{Conceptual model and analysis}

The following two models have been conceptualized:

Model-I to examine the impact of organizational service quality on distributor service quality, Model-II to examine the impact of distributor service quality on satisfaction, and loyalty.

5.1 Model-I: This model is conceptualized to evaluate the impact of OSQ on DSQ. Figure 8 depicts schematic diagram of structural relationship between exogenous latent variable OSQ and endogenous latent variable DSQ using factors of the scales as identified by EFA followed by CFA. 


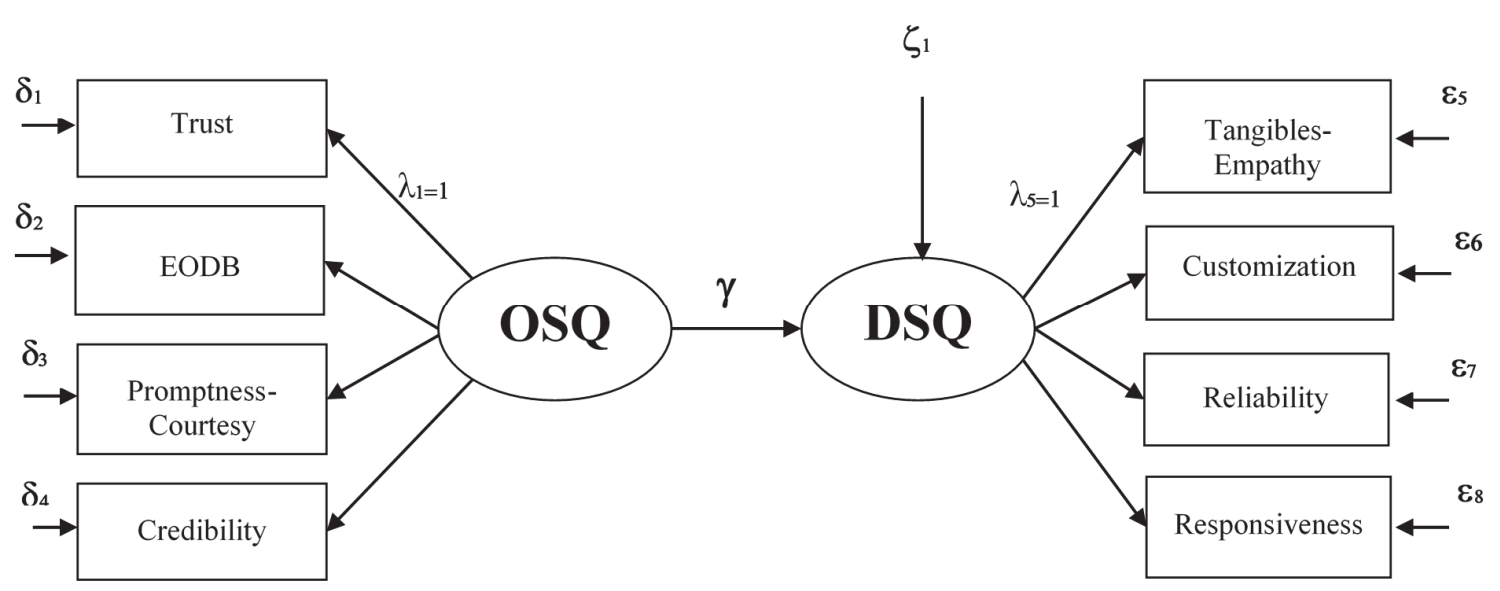

Fig. 8. Conceptual Model representing the relationship between OSQ and DSQ

\section{Notations:}

$\lambda$ : Factor loadings in measurement part of OSQ/DSQ

$\delta$ : Residual errors in measurement part of OSQ

$\gamma$ : Path Coefficient from OSQ to DSQ

$\varepsilon$ : Residual errors in measurement part of DSQ

$\zeta$ : Residual error in DSQ

\subsubsection{Analysis of Model I}

Proposition 1: Organizational service quality is a source of extrinsic service quality. The following hypothesis is developed for testing this relationship:

\begin{tabular}{lll}
\hline S. No. & Null Hypothesis $\left(\mathbf{H}_{\mathbf{0}}\right)$ & Alternative Hypothesis (Ha) \\
\hline $\mathrm{H}_{1}$ & $\begin{array}{l}\text { Path coefficient } \gamma \text { is not significantly } \\
\text { different form } 0 .\end{array}$ & $\begin{array}{l}\text { Organizational service quality is positively } \\
\text { linked to distributor service quality. }\end{array}$ \\
\hline
\end{tabular}

\subsubsection{Model Fit}

Various goodness-of-fit indices are obtained by running the model using AMOS v21. The Normed Chisquare value for this model is 2.431 , which represents a good fit. The acceptable ratio of Normed Chisquare value is up to 3 or even 5 (Bollen, 1989; Tanaka, 1987; Jafarinezhad et al., 2016). The Goodnessof- Fit Index (GFI), the Comparative Fit Index (CFI) and the Normed Fit Index (NFI) values for this model were $0.978,0.986$, and 0.976 respectively. The RMSR value of 0.021 and RMSEA value of 0.012 indicates a reasonable fit. From these values it is inferred that model represents an adequate fit. Fig. 9 depicts the pictorial representation of various path estimates of the model-I.

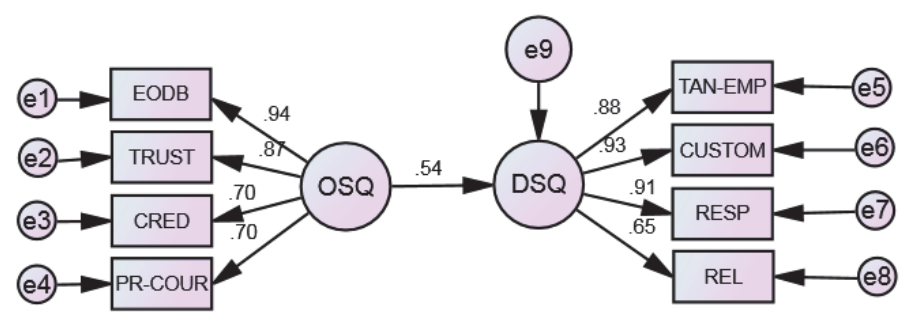

Fig. 9. Path estimates of Model-I 
Various path estimates between exogenous and endogenous latent variables of the model-I are depicted in Table 13.

Table 13

Regression Weights for Model-I

\begin{tabular}{lc}
\hline Path & Standardized Regression Weight Estimate \\
\hline OSQ to DSQ & 0.54 \\
OSQ to EODB & $\mathbf{0 . 9 4}$ \\
OSQ to Trust & 0.87 \\
OSQ to Credibility & 0.70 \\
OSQ to Promptness-Courtesy & 0.70 \\
DSQ to Tangibles-Empathy & 0.88 \\
DSQ to Customization & $\mathbf{0 . 9 3}$ \\
DSQ to Responsiveness & 0.91 \\
\hline DSQ to Reliability & 0.65 \\
\hline
\end{tabular}

All the regression weights were significant which is in line with the hypothesized relationships. The magnitude of the estimated parameters provides information on the strength of the hypothesized relationships. The regression weight for the $E O D B$ dimension was highest for organizational service quality towards distributor, whereas the regression weight for Customization was highest for measuring distributor service quality in such units. The Standardized Regression Weight for the path linking exogenous latent variable organizational service quality to endogenous latent variable distributor service quality was 0.54 which was found to be significant at a significance level of $5 \%$. Therefore, the alternative hypothesis $\mathrm{H}_{\mathrm{a}}$ of organizational service quality (i.e. service quality offered by manufacturing unit towards its distributor) positively impacting the distributor service quality (i.e., service quality delivered by the distributor) is accepted.

\subsection{Model-II}

The model-II is conceptualized to understand the relationship between OSQ and DSQ with satisfaction and loyalty at manufacturing unit-distributor interface. The conceptual structural model for this relationship is depicted in Fig. 10.

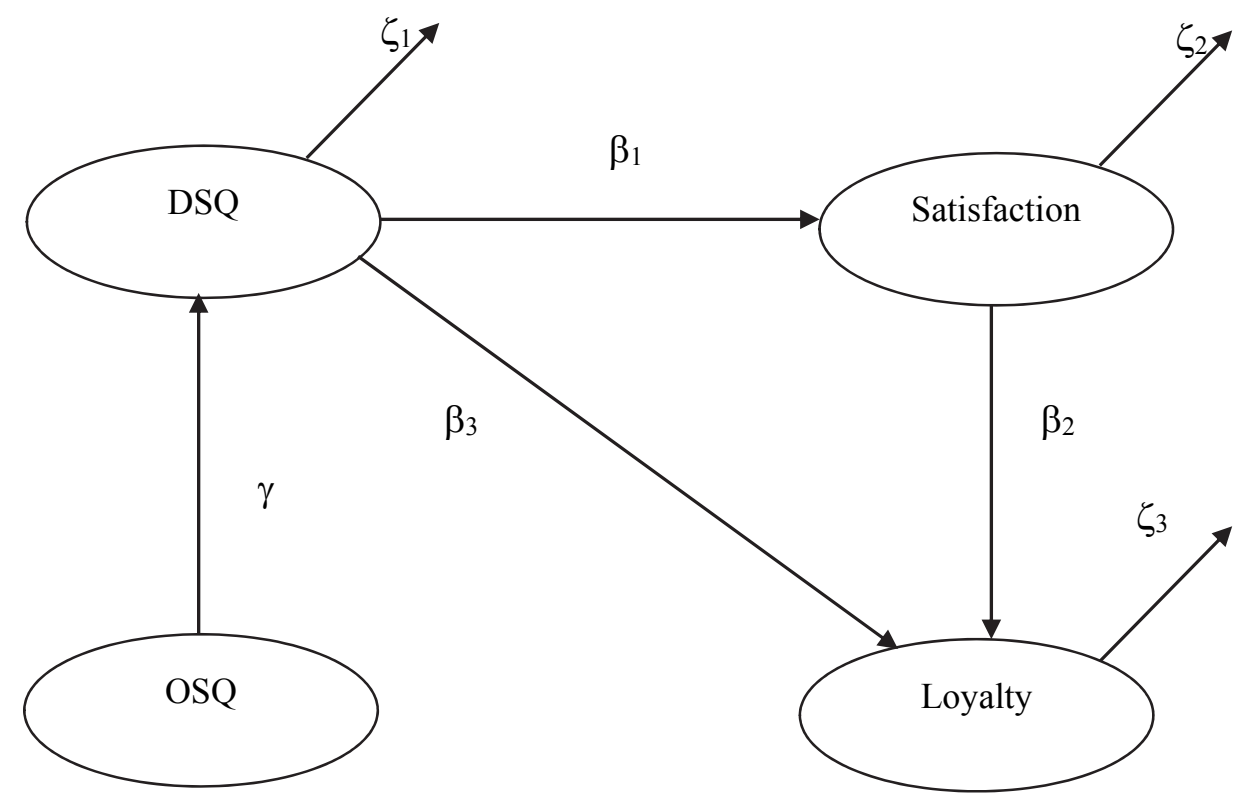

Fig. 10. Conceptual Structural Model-II

\section{Notations:}


$\gamma$ : Path Coefficient from OSQ $\rightarrow$ DSQ

$\beta_{1}, \beta_{2}, \beta_{3}$ : Path Coefficients from DSQ $\rightarrow$ Satisfaction; DSQ $\rightarrow$ Loyalty, Satisfaction $\rightarrow$ Loyalty resp.

$\zeta_{1}, \zeta_{2}, \zeta_{3}:$ Residual error in measurement of DSQ, Satisfaction and Loyalty respectively

\subsubsection{Analysis of Model-II}

Proposition 2: Distributor service quality is a source of Satisfaction.

Proposition 3: Satisfaction is a source of Loyalty.

Proposition 4: Distributor service quality is a source of Loyalty.

The following hypotheses are developed for testing this relationship:

\begin{tabular}{cll}
\hline S. No. & Null Hypothesis $\left(\mathbf{H}_{\mathbf{0}}\right)$ & Alternative Hypothesis (Ha) \\
\hline $\mathbf{H}_{\mathbf{2}}$ & $\begin{array}{l}\mathrm{H}_{0} 2 \text { : Path coefficient } \beta_{1} \text { is not significantly } \\
\text { different from } 0 .\end{array}$ & $\begin{array}{l}\mathrm{H}_{\mathrm{a}} 2 \text { : DSQ is positively linked with satisfaction as poof } \\
\text { manufacturing unit. }\end{array}$ \\
$\mathbf{H}_{4}$ & $\begin{array}{l}\mathrm{H}_{0} 3 \text { : Path coefficient } \beta_{2} \text { is not significantly } \\
\text { different from } 0 .\end{array}$ & $\begin{array}{l}\mathrm{H}_{\mathrm{a}} 3 \text { : Satisfaction from the distributor } \text { positively } \\
\text { impacts loyalty. }\end{array}$ \\
$\mathbf{H}_{4}$ & $\begin{array}{l}\mathrm{H}_{0} 4: \text { Path coefficient } \beta_{3} \text { is not significantly } \\
\text { different from } 0 .\end{array}$ & $\begin{array}{l}\mathrm{H}_{\mathrm{a}} 4 \text { : Distributor service quality is positively with } \\
\text { loyalty. }\end{array}$ \\
\hline
\end{tabular}

\subsubsection{Model Fit}

Various goodness-of-fit indices are obtained by running the model using AMOS v21. The Normed Chisquare value for this model is 2.222 , which represents a good fit. The acceptable ratio of Normed Chisquare value is up to 3 or even 5 (Bollen, 1989; Tanaka, 1987). The Goodness-of Fit Index (GFI), the Comparative Fit Index (CFI) and the Normed Fit Index (NFI) values for this model were 0.923, 0.962, and 0.911 respectively. The RMSR value of 0.035 and RMSEA value of 0.055 indicate a reasonable fit. From these values it is inferred that model represents an adequate fit. Figure 11 depicts the pictorial representation of various path estimates of the model-II.

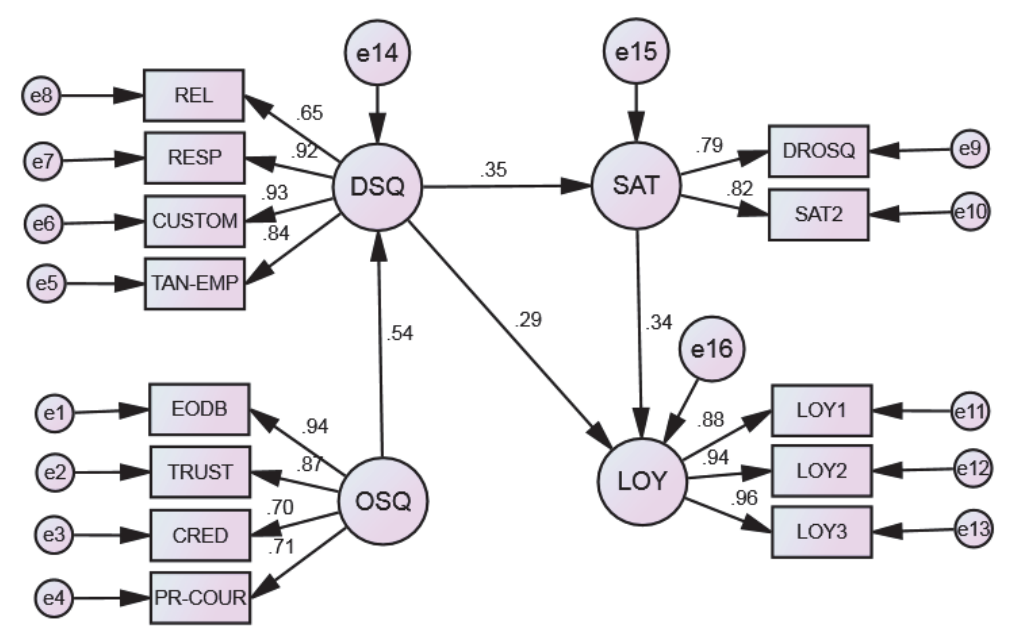

Fig. 11. Path estimates of Model-II

The positive signs of the parameters representing the paths between the latent variables are in line with hypothesized relationships. The Standardized Regression Weight for the path linking DSQ to Satisfaction was 0.35 which was found to be significant at a significance level of .05. Therefore, the alternative hypothesis $\mathrm{H}_{\mathrm{a}} 2$ of distributor service quality (i.e., service quality delivered by the distributor) positively impacting the Satisfaction is accepted. The Standardized Regression Weight for the path linking Satisfaction to Loyalty was 0.34 which was found to be significant at a significance 
level of $5 \%$. Therefore, the alternative hypothesis $\mathrm{H}_{\mathrm{a}} 3$ of Satisfaction positively impacting the Loyalty is accepted. The Standardized Regression Weight for the path linking DSQ to Loyalty was 0.29 which was found to be significant at a significance level of 5\%. Therefore, the alternative hypothesis $\mathrm{H}_{\mathrm{a}} 4$ of $E S Q$ positively impacting the Loyalty is accepted.

\section{Conclusion}

The present study was intended to study a) organizational service quality offered by the manufacturing unit towards facilitation of working of its distributor; b) distributor service quality delivered by distributor; and c) the relationship of these constructs i.e. OSQ and DSQ with satisfaction and loyalty measures. The insights provided by this study can help managers and researchers in further understanding the service quality issues relating to distribution function in SMEs. This paper also comes out with a set of four hypotheses related to service quality at the manufacturer-distributor interface. The model is analyzed using data collected from 101 small-medium manufacturing units situated in North India and it is found that data fits the model. Some of the typical benefits are:

i. The proposed structure fills the gaps that exist in the conceptualization of service quality issues related to marketing and distribution functions in small-medium enterprises of emerging economies like India. The study brings out useful determinants (four each) to measure both organizational as well as distributor service quality. The scores on individual sub-dimensions indicate suggestions for improvements to managers along those areas.

ii. The OSQ and DSQ scales can also be used as diagnostic tools for identifying poor and/or excellent performance to benchmark across multiple departments within a single manufacturing unit. Furthermore, any of these situations can also be compared across time. These scales can be enlarged to take care of other industries too.

iii. The study also derived linkages between organizational and distributor service quality with satisfaction and loyalty based on structural equation modeling. SME practitioners must realize that their ability to provide good service quality to distributor reflects in their enhanced level of service delivery which inspires their loyalty to the unit.

iv. Findings of this paper demonstrate that the flow of service elements embedded in the flow of products is a source of value addition at manufacturer-distributor interface. However, these findings can be extended to add supplier, retailer and end user's perspective. Traditionally, service quality driven operations have been overlooked in such units with an understanding that transaction specific opportunistic approach may work best for SMEs.

Grönroos (1990) argues that in the distribution of products the quality of service is a major factor in competition. This may be more relevant in the SME clusters where manufacturers produce intrinsically similar products. This study demonstrates that high service quality is increasingly important as a tool which is used by the manufacturers towards their distributors. The service quality provided by the manufacturer and the distributor to each other helps in establishing close relationships. Close relationships are important in creating mutual commitment and understanding. Various empirical studies on the distribution function demonstrate that satisfaction is derived from relationships between the manufacturer and the distributor. This study too finds the link between satisfaction and service quality. This finding is in line those of other scholars who report that satisfaction results from satisfaction with products and services (Ghosh et al., 1997) and satisfaction with various facets of the manufacturing organization (i.e., manufacturers) such as financial or social aspects (Michie \& Sibly, 1985).

\section{Implication for practice}

This paper should be of interest to manufacturing industry practitioners interested in service quality improvement w.r.t. their distributor to create a win-win situation. Therefore, managers should focus their efforts in managing organizational service quality directed towards distributor. The scales could 
serve as a useful toolkit for managers to assess the relative strengths and weaknesses with respect to various dimensions of service quality, and accordingly, concentrate their efforts on strengthening the weak areas.

In general, all entities in a manufacturing unit play dual role of buyer as well as customer. Perceptions developed while performing the role of customer help the supply chain actor in assuming the role of seller at the subsequent level. When both of these views would be in synchronization with each other they will promote balanced and harmonious view of relationship and seamless working. In Indian SMEs too, manufacturing is evolving from materials orientation towards the service driven manufacturing. This recognition is important given the scope of such units in emerging economies across the world and the market size whose potential is still untapped.

\section{Limitations and scope for future study}

A small geographical spread, a small sample size and snowball sampling precludes much of the generalizability of the study findings. In this paper the unit of analysis has been individual respondents; future researchers may take single organization as a unit of analysis. This research takes the functional perspective of service quality and uses unweighted "performance only" measures for analysis of service quality. These two could be other limitations of the paper. Adapting this model across different manufacturing industries would be an interesting area of research. This paper used survey method as the main methodology. However, case study method in conjunction with other methods may also be used to gather more insightful findings.

\section{References}

Abasi, N., Azad, N., \& Hafashjani, K. (2015). Information systems success: the quest for the dependent variable. Uncertain Supply Chain Management, 3(2), 181-188.

Abdul-Muhmin, A. G. (2002). Effects of suppliers' marketing program variables on industrial buyers' relationship satisfaction and commitment. Journal of Business \& Industrial Marketing, 17(7), 637-651.

Ahire, S. L., Golhar, D. Y., \& Waller, M. A. (1996). Development and validation of TQM implementation constructs. Decision sciences, 27(1), 23-56.

Ahmad, N., Usman Awan, M., Raouf, A., \& Sparks, L. (2009). Development of a service quality scale for pharmaceutical supply chains. International journal of pharmaceutical and healthcare marketing, 3(1), 26-45.

Anderson, J. C., \& Narus, J. A. (1990). A model of distributor firm and manufacturer firm working partnerships. the Journal of Marketing, 54(1), 42-58.

Bagozzi, R. P., \& Yi, Y. (1988). On the evaluation of structural equation models. Journal of the academy of marketing science, 16(1), 74-94.

Bagozzi, R. P., Yi, Y., \& Phillips, L. W. (1991). Assessing construct validity in organizational research. Administrative Science Quarterly, 36(3), 421-458.

Bienstock, C. C., Mentzer, J. T., \& Bird, M. M. (1997). Measuring physical distribution service quality. Journal of the Academy of Marketing Science, 25(1), 31.

Bollen, K. A., \& Ting, K. F. (1993). Confirmatory tetrad analysis. Sociological Methodology, 23, 147-175.

Bookbinder, J. H., \& Lynch, M. E. (1997). Customer service in physical distribution: A utility-function approach. International Journal of Physical Distribution \& Logistics Management, 27(9/10), 540-558.

Bowersox, D. J., Closs, D. J., \& Stank, T. P. (1999). 21 st century logistics: making supply chain integration a reality.

Bryne, B. M. (1994). Structural equation modeling with EQS and EQS/Windows. Thousand Oaks, Califomia: Sage Publications.

Bucklin, L. P., \& Sengupta, S. (1993). Organizing successful co-marketing alliances. The Journal of Marketing, 57(2), 32-46.

Buttle, F. (1996). SERVQUAL: review, critique, research agenda. European Journal of Marketing, 30(1), 8-32. 
Carr, C. L. (2007). The FAIRSERV model: Consumer reactions to services based on a multidimensional evaluation of service fairness. Decision Sciences, 38(1), 107-130.

Cavusgil, S. T., Deligonul, S., \& Zhang, C. (2004). Curbing foreign distributor opportunism: An examination of trust, contracts, and the legal environment in international channel relationships. Journal of International Marketing, 12(2), 7-27.

Cavusgil, S. T., Yeoh, P. L., \& Mitri, M. (1995). Selecting foreign distributors: An expert systems approach. Industrial Marketing Management, 24(4), 297-304.

Chin, W. W., Marcolin, B. L., \& Newsted, P. R. (2003). A partial least squares latent variable modeling approach for measuring interaction effects: Results from a Monte Carlo simulation study and an electronic-mail emotion/adoption study. Information Systems Research, 14(2), 189-217.

Cronin Jr, J. J., \& Taylor, S. A. (1992). Measuring service quality: a reexamination and extension. The journal of marketing, 56(3), 55-68.

Cunningham, L. F., Young, C. E., \& Lee, M. (2002). Cross-cultural perspectives of service quality and risk in air transportation.

Dabholkar, P. A., Shepherd, C. D., \& Thorpe, D. I. (2000). A comprehensive framework for service quality: an investigation of critical conceptual and measurement issues through a longitudinal study. Journal of Retailing, 76(2), 139-173.

Dahistrom, R., McNeilly, K. M., \& Speh, T. W. (1996). Buyer-seller relationships in the procurement of logistical services. Journal of the Academy of Marketing Science, 24(2), 110-124.

Das, C., \& Tyagi, R. (1994). Wholesaler: a decision support system for wholesale procurement and distribution. International Journal of Physical Distribution \& Logistics Management, 24(10), 4-12.

Devinder, K., \& Datta, B. (2003). A study of the effect of perceived lecture quality on post-lecture intentions. Work Study, 52(5), 234-243.

Dwyer, F. R. (1980). Channel-Member Satisfaction-Laboratory Insights. Journal of Retailing, 56(2), $45-$ 65.

Dwyer, F. R., Schurr, P. H., \& Oh, S. (1987). Developing buyer-seller relationships. The Journal of marketing, 51(2), 11-27.

Emerson, C. J., \& Grimm, C. M. (1996). Logistics and marketing components of customer service: an empirical test of the Mentzer, Gomes and Krapfel model. International Journal of Physical Distribution \& Logistics Management, 26(8), 29-42.

Erengüç, Ş. S., Simpson, N. C., \& Vakharia, A. J. (1999). Integrated production/distribution planning in supply chains: An invited review. European Journal of Operational Research, 115(2), 219-236.

Erol, I., \& Ferrell Jr, W. G. (2004). A methodology to support decision making across the supply chain of an industrial distributor. International Journal of Production Economics, 89(2), 119-129.

Farquhar, P. H. (1984). State of the art—utility assessment methods. Management Science, 30(11), 12831300.

Finn, D. W. (1991). An evaluation of the SERVQUAL scales in a retailing setting. ACR North American Advances.

Flynn, B. B., Sakakibara, S., Schroeder, R. G., Bates, K. A., \& Flynn, E. J. (1990). Empirical research methods in operations management. Journal of Operations Management, 9(2), 250-284.

Fornell, C., \& Larcker, D. F. (1981). Evaluating structural equation models with unobservable variables and measurement error. Journal of Marketing Research, 18(1), 39-50.

Forza, C. (2016). Surveys. In Research Methods for Operations Management (pp. 95-180). Routledge.

Frazier, G. L. (1983). On the measurement of interfirm power in channels of distribution. Journal of Marketing research, 20(2), 158-166.

Gaski, J. F. (1984). The theory of power and conflict in channels of distribution. the Journal of Marketing, 48(3), 9-29.

Ghosh, A. K., Joseph, W. B., Gardner, J. T., \& Thach, S. V. (1997). Antecedents, outcomes, and moderating influences on industrial distributors' satisfaction with supplier relationships. Journal of Marketing: Theory and Practice, 5(4), 58-67.

Goodman, L. E., \& Dion, P. A. (2001). The determinants of commitment in the distributor-manufacturer relationship. Industrial Marketing Management, 30(3), 287-300.

Grönroos, C. (1990). Service management and marketing: Managing the moments of truth in service competition. Jossey-Bass. 
Gundlach, G. T., Achrol, R. S., \& Mentzer, J. T. (1995). The structure of commitment in exchange. the Journal of Marketing, 59(1), 78-92.

Gupta, T. K., \& Singh, V. (2015). A systematic approach to evaluate supply chain management environment index using graph theoretic approach. International Journal of Logistics Systems and Management, 21(1), 1-45.

Hair Jr, J. F., Black, W. C., Babin, B. J., Anderson, R. E., \& Tatham, R. L. (2010). SEM: An introduction. Multivariate data analysis: A global perspective, 629-686.

Hunt, I., \& Jones, R. (1998). Winning new product business in the contract electronics industry. International Journal of Operations \& Production Management, 18(2), 130-142.

Jafarinezhad, S., Zangeneh, G., \& Naami, A. (2016). The effect of customer segmentation factors on export performance of SMEs. Uncertain Supply Chain Management, 4(1), 77-82.

Joseph, W. B., Gardner, J. T., Thach, S., \& Vernon, F. (1995). How industrial distributors view distributorsupplier partnership arrangements. Industrial Marketing Management, 24(1), 27-36.

Kalafatis, S. P. (2002). Buyer-seller relationships along channels of distribution. Industrial Marketing Management, 31(3), 215-228.

Kang, H., \& Bradley, G. (2002). Measuring the performance of IT services: An assessment of SERVQUAL. International Journal of Accounting Information Systems, 3(3), 151-164.

Kumar, A., \& Sharman, G. (1992). We love your product, but where is it?. Sloan Management Review, 33(2), 93.

Lambert, D. M., Emmelhainz, M. A., \& Gardner, J. T. (1999). Building successful logistics partnerships. Journal of Business Logistics, 20(1), 165.

Lee, H., Lee, Y., \& Yoo, D. (2000). The determinants of perceived service quality and its relationship with satisfaction. Journal of Services Marketing, 14(3), 217-231.

Li, L., \& Lee, Y. S. (1994). Pricing and delivery-time performance in a competitive environment. Management Science, 40(5), 633-646.

Ma, H. Z., \& Deng, Z. Q. (2002). Architecture of methodology for distribution chain design. In Proceedings of International Conference on e-Business (ICEB2002).

Ma, H., Deng, Z., \& Deng Solvang, W. (2004). An online approach for distributor benchmarking. Benchmarking: An International Journal, 11(4), 385-402.

MacDuffie, J. P., \& Helper, S. (1997). Creating lean suppliers: diffusing lean production through the supply chain. California Management Review, 39(4), 118-151.

Mentzer, J. T., Gomes, R., \& Krapfel Jr, R. E. (1989). Physical distribution service: a fundamental marketing concept?. Journal of the Academy of Marketing Science, 17(1), 53-62.

Merritt, N. J., \& Newell, S. J. (2001). The extent and formality of sales agency evaluations of principals. Industrial Marketing Management, 30(1), 37-49.

Michie, D. A., \& Sibley, S. D. (1985). Channel member satisfaction: controversy resolved. Journal of the Academy of Marketing Science, 13(1-2), 188-205.

Min, H., \& Melachrinoudis, E. (1999). The relocation of a hybrid manufacturing/distribution facility from supply chain perspectives: a case study. Omega, 27(1), 75-85.

Morgan, D. (Ed.). (1993). Successful focus groups: Advancing the state of the art (Vol. 156). Sage Publications.

Morgan, R. M., \& Hunt, S. D. (1994). The commitment-trust theory of relationship marketing. The Journal of Marketing, 58(3), 20-38.

Morris, M., \& Carter, C. R. (2005). Relationship marketing and supplier logistics performance: An extension of the key mediating variables model. Journal of Supply Chain Management, 41(4), 32-43.

Mudambi, S., \& Aggarwal, R. (2003). Industrial distributors: can they survive in the new economy?. Industrial Marketing Management, 32(4), 317-325.

Nadali, S., Zarifi, S., \& Shirsavar, H. (2017). Identifying and ranking the supply chain management factors influencing the quality of the products. Uncertain Supply Chain Management, 5(1), 43-50.

Narus, J. A., \& Anderson, J. C. (1986). Turn your industrial distributors into partners. Marketing Management and Strategy: A Reader, 64, 66-71.

Narus, J. A., \& Anderson, J. C. (1988). Strengthen distributor performance through channel positioning. MIT Sloan Management Review, 29(2), 31.

Nunnally, J. C., \& Bernstein, I. H. (1978). Psychometric theory. 
Ozment, J., \& Chard, D. N. (1986). Effects of customer service on sales: An analysis of historical data. International Journal of Physical Distribution \& Materials Management, 16(3), 14-28.

Parasuraman, A., Zeithaml, V. A., \& Berry, L. L. (1985). A conceptual model of service quality and its implications for future research. The Journal of Marketing, 41-50.

Parasuraman, A., Zeithaml, V. A., \& Berry, L. L. (1988). SERVQUAL: A multiple-item scale for measuring consumer perception of service quality, Journal of Retailing, 64(1), 12.

Parmata, U. M. D. (2016). Measuring service quality in pharmaceutical supply chain-distributor's perspective. International Journal of Pharmaceutical and Healthcare Marketing, 10(3), 258-284.

Patterson, P. G., Johnson, L. W., \& Spreng, R. A. (1996). Modeling the determinants of customer satisfaction for business-to-business professional services. Journal of the Academy of Marketing Science, 25(1), 4-17.

Perreault, W. D., \& Russ, F. A. (1976). Quantifying marketing trade-offs in physical distribution policy decisions. Decision Sciences, 7(2), 186-201.

Pisharodi, M. R., \& Langley, C. J. (1991). Interset association between measures of customer service and market response. International Journal of Physical Distribution \& Logistics Management, 21(2), 32-44.

Pitt, L. F., Watson, R. T., \& Kavan, C. B. (1995). Service quality: a measure of information systems effectiveness. MIS Quarterly, 19(2), 173-187.

Prakash, G. (2011). Service quality in supply chain: empirical evidence from Indian automotive industry. Supply Chain Management: An International Journal, 16(5), 362-378.

Robson, C. (2002). Real world research. 3. uppl.

Saunders, M., Lewis, P., \& Thornhill, A. (2009). Understanding research philosophies and approaches. Research Methods for Business Students, 4, 106-135.

Schellhase, R., Hardock, P., \& Ohlwein, M. (2000). Customer satisfaction in business-to-business marketing: The case of retail organizations and their suppliers. The Journal of Business and Industrial Marketing, 15(2-3), 106-121.

Seth, N., Deshmukh, S. G., \& Vrat, P. (2006). A framework for measurement of quality of service in supply chains. Supply Chain Management: An International Journal, 11(1), 82-94.

Shipley, D., \& Jobber, D. (1994). Size Effects on Sales Mangement Practices of Small Firms: A Study of Industrial Distributors. Journal of Personal Selling \& Sales Management, 14(1), 31-43.

Simpson, P. M., Siguaw, J. A., \& White, S. C. (2002). Measuring the performance of suppliers: an analysis of evaluation processes. Journal of Supply Chain Management, 38(4), 29-41.

Sink, H. L., \& Langley Jr, C. J. (1997). A managerial framework for the acquisition of third-party logistics services. Journal of business logistics, 18(2), 163.

Siu, N. Y., \& Tak-Hing Cheung, J. (2001). A measure of retail service quality. Marketing Intelligence \& Planning, 19(2), 88-96.

Smith, P. M., Ross, E. S., \& Smith, T. (1997). A case study of distributor-supplier business relationships. Journal of Business Research, 39(1), 39-44.

Sureshchandar, G. S., Rajendran, C., \& Anantharaman, R. N. (2002). Determinants of customer-perceived service quality: a confirmatory factor analysis approach. Journal of Services Marketing, 16(1), 9-34.

Tanaka, J. S. (1987). How big is big enough?: Sample size and goodness of fit in structural equation models with latent variables. Child Development, 58(1), 134-146.

Trochim, W. M. (2007). Research methods, Biztantra, New Delhi.

Wilkinson, I. (1981). Power, conflict, and satisfaction in distribution channels-an empirical study. International Journal of Physical Distribution \& Materials Management, 11(7), 20-30.

Zhao, X., Bai, C., \& Hui, Y. V. (2002). An empirical assessment and application of SERVQUAL in a mainland Chinese department store. Total Quality Management, 13(2), 241-254.

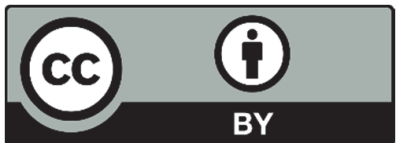

(C) 2018 by the authors; licensee Growing Science, Canada. This is an open access article distributed under the terms and conditions of the Creative Commons Attribution (CC-BY) license (http://creativecommons.org/licenses/by/4.0/). 